\title{
Effect of one-week ethanol treatment on monoamine levels and dopaminergic receptors in rat striatum
}

S.M.M. Vasconcelos,

D.S. Macêdo,

L.O. Lima, F.C.F. Sousa,

M.M.F. Fonteles

and G.S.B. Viana
Departamento de Fisiologia e Farmacologia, Faculdade de Medicina, Universidade Federal do Ceará, Fortaleza, CE, Brasil

\section{Correspondence \\ G. Viana \\ Departamento de Fisiologia e \\ Farmacologia \\ Faculdade de Medicina, UFC \\ Rua Cel. Nunes de Melo, 1127 \\ 60431-270 Fortaleza, CE \\ Brasil \\ Fax: +55-85-288-8333 \\ E-mail: osorio@roadnet.com.br \\ Research supported by CNPq.}

Received July 18, 2002

Accepted November 29, 2002

\section{Abstract}

We studied the effects of ethanol on the levels of norepinephrine, dopamine, serotonin (5-HT) and their metabolites as well as on D1and D2-like receptors in the rat striatum. Ethanol ( 2 or $4 \mathrm{~g} / \mathrm{kg}, p o$ ) was administered daily by gavage to male Wistar rats and on the 7th day, 30 min or $48 \mathrm{~h}$ after drug administration, the striatum was dissected for biochemical assays. Monoamine and metabolite concentrations were measured by HPLC and D1- and D2-like receptor densities were determined by binding assays. Scatchard analyses showed decreases of 30 and $43 \%$, respectively, in D1- and D2-like receptor densities and no change in dissociation constants (Kd) $48 \mathrm{~h}$ after the withdrawal of the dose of $4 \mathrm{~g} / \mathrm{kg}$. Ethanol, $2 \mathrm{~g} / \mathrm{kg}$, was effective only on the density of D2-like receptors but not on Kd of either receptor. Thirty minutes after the last ethanol injection $(4 \mathrm{~g} / \mathrm{kg})$, decreases of D2 receptor density (45\%) as well as of $\mathrm{Kd}$ values (34\%) were detected. However, there was no significant effect on D1-like receptor density and a $46 \%$ decrease was observed in $\mathrm{Kd}$. An increase in dopamine and 3,4dihydroxyphenylacetic acid (DOPAC), a decrease in norepinephrine, and no alteration in 5-HT levels were demonstrated after 48-h withdrawal of $4 \mathrm{~g} / \mathrm{kg}$ ethanol. Similar effects were observed in dopamine and DOPAC levels $30 \mathrm{~min}$ after drug administration. No alteration in norepinephrine concentration and a decrease in 5-HT levels were seen $30 \mathrm{~min}$ after ethanol $(4 \mathrm{~g} / \mathrm{kg})$ administration. Our findings indicate the involvement of the monoaminergic system in the responses to ethanol.

\section{Introduction}

Acute or chronic alcohol consumption interferes differentially with transmission processes in the central nervous system, affecting many if not all of the known neurotransmitter systems (1). However, the mechanisms by which ethanol produces its effects within the central nervous system are only now beginning to be understood (2). It is
Key words

- Rat striatum

- Dopamine

- Serotonin

- Alcohol ingestion

- Noradrenaline

- D1 and D2 receptor density

- $\mathrm{Kd}$ possible that the behavioral effect of ethanol is related to the dopaminergic system. However, dopamine release is likely to be secondary to GABAergic receptor activation by ethanol.

The results of studies of the effects of repeated ethanol administration on dopaminergic D1- and D2-like receptors appear contradictory and inconclusive. Thus, Lograno et al. (3) demonstrated that an 8-week ethanol treatment $(3 \%, v / v)$ increases the number 
of dopamine D1 receptor sites in the rat caudate putamen with no alteration in D2 receptor density. Also, Hruska (4) observed that ethanol administered in a completely liquid diet for 21 days produced an increase in the density of striatal D1 or D2 receptors without altering receptor affinity. On the other hand, Pellegrino and Druse (5) demonstrated that rat consumption of a $6.6 \%(\mathrm{v} / \mathrm{v})$ ethanol-containing lipid diet for 1 month caused a $25 \%$ loss of D1 receptors in the nucleus accumbens and no differences in D1 and D2 receptors in the striatum. Similarly, Lucchi et al. (6) observed that chronic exposure to ethanol ( $6 \%$ in drinking water for 25 days) decreased the density of both D1 and D2 receptors in rat striatal membranes.

Administration of ethanol induces release of dopamine and serotonin (5-HT) (7-9) in the caudate nucleus and nucleus accumbens of freely moving rats, while acute alcohol withdrawal reduces extracellular dopamine concentrations in the nucleus accumbens (10). These findings strengthened the hypothesis that dopamine is critical for mediating the reinforcing and rewarding effects of the substance in the brain (11). Clinical studies indicate that 5-HT re-uptake inhibitors exhibit some efficacy in reducing alcoholism (12). The site of action of the 5-HT re-uptake inhibitors is unknown, but they may be acting somewhere in central reward pathways to modify the action of ethanol (13).

Because ethanol seems to affect several neurotransmitter systems we determined its effect on rat striatal concentrations of norepinephrine, dopamine and 5-HT as well as its effect on D1- and D2-like receptor density and binding constants in order to identify the mechanisms of the central action of ethanol. Thus, we investigated the effects of repeated daily administration of ethanol for 7 days at two doses and at $30 \mathrm{~min}$ and $48 \mathrm{~h}$ after the last drug administration on D1- and D2-like receptor densities, and on levels of norepinephrine, dopamine, 5-HT and their metabolites in rat striatum.

\section{Material and Methods}

\section{Animals}

Male Wistar rats (150-200 g) had free access to a commercial diet (Purina, Campinas, SP, Brazil) and water, and were housed in a room with a 12-h on-and-off lighting schedule. All experiments were performed according to the Guide for the Care and Use of Laboratory Animals obtained from the US Department of Health and Human Services (14).

\section{Drugs}

A 20\% ethanol solution (Vetec, Rio de Janeiro, RJ, Brazil) was diluted in distilled water and administered by gavage in volumes of 2 or $4 \mathrm{ml} / \mathrm{kg}$ body weight (corresponding to 2 or $4 \mathrm{~g} / \mathrm{kg}$, po, respectively). All drugs were of analytical grade.

\section{Treatment}

Animals were treated daily at noon for 7 days with ethanol ( 2 or $4 \mathrm{~g} / \mathrm{kg}, p o$ ) by gavage and sacrificed $30 \mathrm{~min}$ or $48 \mathrm{~h}$ after the last drug administration. Controls received an equivalent volume of distilled water. Biochemical parameters were determined in two conditions: a) in the presence of alcohol in plasma (30 min after the last drug administration), and b) after ethanol removal from the systemic circulation (after a 48-h withdrawal).

\section{Binding assays}

Dopaminergic D1- and D2-like receptor assays. The methods of Meltzer et al. (15) for D1-like receptors and of Kessler et al. (16) for D2-like receptors were used. Animals (4-6 per group) were decapitated 30 min or $48 \mathrm{~h}$ after ethanol withdrawal, and the striatum was dissected on ice for the preparation of a $10 \%(\mathrm{w} / \mathrm{v})$ homogenate. The ho- 
mogenate containing $60-120 \mu \mathrm{g}$ of protein was incubated in $50 \mu \mathrm{M}$ Tris- $\mathrm{HCl}$ buffer, $\mathrm{pH}$ 7.4 , in the presence of $10 \mu \mathrm{M}$ mianserin (Organon, São Paulo, SP, Brazil), to block serotonergic receptors, in the case of D2like receptor binding assay. Several ligand concentrations of $\left[{ }^{3} \mathrm{H}\right]-\mathrm{SCH}-23390(109 \mathrm{Ci} /$ mmol, Amersham, Uppsala, Sweden), from 0.135 to $6.75 \mathrm{nM}$, or $\left[{ }^{3} \mathrm{H}\right]$-spiroperidol (109 $\mathrm{Ci} / \mathrm{mmol}$, Amersham), 0.09 to $4.76 \mathrm{nM}$, were used for D1- and D2-like receptors, respectively, in a final volume of $0.2 \mathrm{ml}$. Reaction media were incubated at $37^{\circ} \mathrm{C}$ for $60 \mathrm{~min}$, and the reaction was terminated by filtration through Whatman GF/B filter paper on a cell harvester apparatus from Brandel (Gaithersburg, MD, USA). Filters were washed five times with cold saline, dried in the oven for $2 \mathrm{~h}$ at $60^{\circ} \mathrm{C}$, and placed in vials containing 3 $\mathrm{ml}$ of a toluene (Vetec)-based scintillation cocktail. Radioactivity was measured with a Beckman LS 100 counter with $61.6 \%$ efficiency. Specific binding was calculated as the total minus nonspecific binding in the presence of $5 \mu \mathrm{M}$ dopamine (Sigma, St. Louis, MO, USA) containing $1 \mathrm{mg} / \mathrm{ml}$ ascorbic acid in order to prevent dopamine degradation.

Data are reported as $\mathrm{fmol} / \mathrm{mg}$ protein (Bmax) and in $\mathrm{nM}$ for the dissociation constant (Kd). These parameters were calculated by the Instat Program for PC computers. Protein was determined by the method of Lowry et al. (17) using bovine serum albumin as standard.

\section{Chemical analysis}

Animals (7-23 per group) were decapitated, and the striatum was dissected on ice for the preparation of a $10 \%(\mathrm{w} / \mathrm{v})$ homogenate. Brain tissue samples were sonicated in 0.5-1 $\mathrm{ml}$ 0.1 M perchloric acid $\left(\mathrm{HClO}_{4}\right.$; Qeel, São Paulo, SP, Brazil) for $30 \mathrm{~s}$ and centrifuged for $15 \mathrm{~min}$ at $26,000 \mathrm{~g}$ at $4^{\circ} \mathrm{C}$. Next, a $20-\mu 1$ supernatant aliquot was injected directly into the high-performance liquid chro- matograph (HPLC) column. For the monoamine analyses, a CLC-ODS (M) Shimadzu (Tokyo, Japan) column was used. The mobile phase was $0.163 \mathrm{M}$ citric acid (Vetec), pH 3.0, containing $20 \mathrm{mM}$ EDTA (Vetec), with $0.69 \mathrm{mM}$ sodium octanesulfonic acid (Sigma), as the ion pair reagent, 4\% (v/v) acetonitrile (Carlo Erba Reagenti, Milan, Italy) and $1.7 \%(\mathrm{v} / \mathrm{v})$ tetrahydrofuran (Sigma). Norepinephrine, dopamine, 3,4-dihydroxyphenylacetic acid (DOPAC), 5-HT, 5hydroxyindoleacetic acid (5-HIAA), and homovanillic acid (HVA) were detected electrochemically using an amperometric detector (Model L-ECD-6A, Shimadzu) by oxidation on a glassy carbon electrode at $0.85 \mathrm{~V}$ relative to an $\mathrm{Ag}-\mathrm{AgCl}$ reference electrode. The amount of neurotransmitters and metabolites in the supernatant solutions were calculated by comparing their peak height with those of standards determined on the same day. Results are reported as ng/g tissue.

\section{Statistical analysis}

All results are reported as means $\pm \mathrm{SEM}$. For the monoamine determinations, and Scatchard analyses of $\left[{ }^{3} \mathrm{H}\right]$-spiroperidol and $\left[{ }^{3} \mathrm{H}\right]-\mathrm{SCH}-23390$ binding data, ANOVA and Tukey as the post hoc test were used to compare results among treatments, and the Student $t$-test was used for comparison between two means. The level of significance was set at $\mathrm{P}<0.05$.

\section{Results}

Scatchard analyses (Table 1) of the $\left[{ }^{3} \mathrm{H}\right]-$ SCH-23390 binding data for rat striatum showed a significant $[\mathrm{F}(2,12)=6.026, \mathrm{P}=$ 0.0192] decrease (about 30\%) of D1-like receptor density (Bmax) only with the high dose of ethanol and the 48-h withdrawal, but there was no alteration in the Kd compared to controls. Similar effects were observed in the $\left[{ }^{3} \mathrm{H}\right]$-spiroperidol binding assays. However, under these conditions significant 
$[\mathrm{F}(2,13)=6.804, \mathrm{P}=0.0119]$ decreases $(39$ and $43 \%$ ) were detected after the repeated administration of 2 and $4 \mathrm{~g} / \mathrm{kg}$ of ethanol respectively, and $\mathrm{Kd}$ values were unchanged (Table 2). At the highest dose ( $4 \mathrm{~g} / \mathrm{kg})$ and 30 min after drug administration, decreases of $45 \%$ in $\mathrm{D} 2$ receptor number $[\mathrm{t}(8)=3.223$, $\mathrm{P}=0.0122]$ and $34 \%$ in $\mathrm{Kd}$ values $[\mathrm{t}(8)=$ $2.557, \mathrm{P}=0.0338]$ were observed as com-

Table 1. Scatchard analysis of $\left[{ }^{3} \mathrm{H}\right]-\mathrm{SCH}-23390$ binding to brain striatum from rats treated daily with ethanol for 7 days and sacrificed $48 \mathrm{~h}$ after the last administration.

\begin{tabular}{lcc}
\hline Group & Bmax (fmol/mg protein) & Kd (nM) \\
\hline Control & $181.3 \pm 7.46(4)$ & $3.67 \pm 0.50(4)$ \\
Ethanol 2 g/kg, po (7 days, 48 h) & $145.0 \pm 16.60(4)$ & $2.67 \pm 0.24(4)$ \\
Ethanol 4 g/kg, po (7 days, 48 h) & $127.5 \pm 8.44(5)^{*}$ & $2.69 \pm 0.41(5)$ \\
\hline
\end{tabular}

Data are reported as means \pm SEM and the number of animals per group is given in parentheses.

${ }^{*} P<0.05$ compared to control (ANOVA and Tukey as the post hoc test).

Table 2. Scatchard analysis of $\left[{ }^{3} \mathrm{H}\right]$-spiroperidol binding to brain striatum from rats treated daily with ethanol for 7 days and sacrificed $48 \mathrm{~h}$ after the last administration.

\begin{tabular}{lcc}
\hline Group & Bmax (fmol/mg protein) & Kd (nM) \\
\hline Control & $288.8 \pm 25.7(6)$ & $3.26 \pm 0.72(6)$ \\
Ethanol 2 g/kg, po (7 days, 48 h) & $176.2 \pm 27.2(4)^{*}$ & $3.86 \pm 0.61(4)$ \\
Ethanol 4 g/kg, po (7 days, 48 h) & $163.3 \pm 29.9(4)^{*}$ & $4.20 \pm 0.47(4)$ \\
\hline
\end{tabular}

Data are reported as means \pm SEM and the number of animals per group is given in parentheses.

${ }^{*} \mathrm{P}<0.05$ compared to control (ANOVA and Tukey as the post hoc test).

Table 3. Scatchard analysis of $\left[{ }^{3} \mathrm{H}\right]-\mathrm{SCH}-23390$ and $\left[{ }^{3} \mathrm{H}\right]-$ spiroperidol binding to brain striatum from rats treated daily with ethanol for 7 days and sacrificed $30 \mathrm{~min}$ after the last administration.

\begin{tabular}{lccccc}
\hline Group & \multicolumn{3}{c}{$\mathrm{D} 1$} & & \multicolumn{2}{c}{$\mathrm{D} 2$} \\
\cline { 2 - 3 } \cline { 5 - 6 } & $\begin{array}{c}\text { Bmax } \\
\text { (fmol/mg protein) }\end{array}$ & $\begin{array}{c}\mathrm{Kd} \\
(\mathrm{nM})\end{array}$ & & $\begin{array}{c}\text { Bmax } \\
\text { (fmol/mg protein) }\end{array}$ & $\begin{array}{c}\mathrm{Kd} \\
(\mathrm{nM})\end{array}$ \\
\hline Control & $164.7 \pm 16.2(5)$ & $4.86 \pm 0.36(5)$ & $253.9 \pm 34.7(5)$ & $2.43 \pm 0.29(5)$ \\
Ethanol (4 g/kg) & $184.6 \pm 11.6(6)$ & $2.63 \pm 0.38(6)^{*}$ & $139.1 \pm 7.96(5)^{*}$ & $1.60 \pm 0.13(5)^{*}$ \\
\hline
\end{tabular}

Data are reported as means \pm SEM and the number of animals per group is given in parentheses.

${ }^{*} \mathrm{P}<0.05$ compared to control (Student $t$-test). pared to controls. No effect was observed on $\mathrm{D} 1$ receptor density $[\mathrm{t}(9)=1.018, \mathrm{P}=0.3353]$, but the $\mathrm{Kd}$ value was decreased by $46 \%[\mathrm{t}(9)=$ 4.173, $\mathrm{P}=0.0024]$ (Table 3).

Figure 1 presents striatal concentrations of norepinephrine, dopamine and 5-HT and their metabolites after 7 days of daily administration of ethanol (2 and $4 \mathrm{~g} / \mathrm{kg}$ ) and $48-\mathrm{h}$ drug withdrawal. Decreases were observed of the order of $48 \%$ in norepinephrine levels with $4 \mathrm{~g} / \mathrm{kg}$ as compared to controls $[\mathrm{F}(2,30)=$ $3.619, \mathrm{P}=0.0400]$. On the other hand, percent increases in dopamine concentrations of similar magnitudes (about $40 \%$ ) were observed with both doses of ethanol $[\mathrm{F}(2,29)=$ $5.073, \mathrm{P}=0.0135$ ] but only with the high dose for DOPAC levels $[\mathrm{F}(2,37)=4.504, \mathrm{P}=$ $0.0182]$. No significant changes were observed in 5-HIAA, 5-HT or HVA levels. An increase in dopamine $(57 \%)$ was also observed after a 30-min administration of repeated ethanol treatment $[\mathrm{t}(13)=5.554$, $\mathrm{P}<0.0001]$. Under these conditions, a large increase in DOPAC (83\%) $[\mathrm{t}(14)=3.972$, $\mathrm{P}=0.0014]$ and a decrease in 5-HT (33\%) $[\mathrm{t}(12)=2.196, \mathrm{P}=0.0485]$ levels were also observed (Figure 2). No alteration was observed in norepinephrine, 5-HIAA or HVA levels $30 \mathrm{~min}$ after the last ethanol ingestion at the dose of $4 \mathrm{~g} / \mathrm{kg}$.

\section{Discussion}

Our data indicate down-regulation of D1like receptors, which was significant 7 days after daily ethanol administration at the dose of $4 \mathrm{~g} / \mathrm{kg}$, po, and $48 \mathrm{~h}$ after the withdrawal, with no change in the $\mathrm{Kd}$ of D1-like receptors. However, $30 \mathrm{~min}$ after the last administration of ethanol (and in the presence of ethanol in plasma), the $\mathrm{Kd}$ value was decreased and Bmax remained unaltered.

Other investigators (18) examining the effects of chronic ethanol (20\% solution) administration after 24- or 48-h withdrawal on $\mathrm{D} 1$ receptors from rat striatum also showed a significant decrease in Bmax and no change 
in $\mathrm{Kd}$. However, the results published in the literature are contradictory, reporting both increases $(3,4)$ and decreases $(6)$, or no differences (5) in D1 receptor number after ethanol treatment. In addition, Hamdi and Prasad (19) suggested that chronic ethanol intake for 1, 2, 3 and 4 weeks, followed by a 10-h withdrawal may cause time-dependent bidirectional changes (i.e., $80 \%$ decrease, $159 \%$ increase, $122 \%$ increase and $85 \%$ decrease as compared to controls after 1, 2, 3 and 4 weeks of ethanol intake, respectively) in rat striatal D1 receptors.

Similarly, there is no consensus regarding the effects of ethanol on D2 receptors, and while some investigators reported an increase (4) others found no difference (6). A recent study (20) reported smaller increases in D2 receptor binding in the ventrolateral caudate putamen of sensitized mice and no difference in other regions including the nucleus accumbens, olfactory bulb and substantia nigra.

In the present study we demonstrated a significant decrease in $\left[{ }^{3} \mathrm{H}\right]$-spiroperidol binding to brain striatum from rats, indicating D2-like receptor down-regulation, with repeated ethanol administration, $48 \mathrm{~h}$ or 30 min after drug administration. Except for a decrease in $\mathrm{Kd} 30 \mathrm{~min}$ after the last ethanol administration, no other change was observed. These apparently contradictory results may be due to the different animal strain and experimental paradigms such as, duration of treatment, time of withdrawal, and ethanol doses used (1). In terms of dopaminergic receptors, prolonged periods of treatment with ethanol leads to specific responses of down-regulation $(6,21)$ based on a general loss of neuroreceptor function. The effects of chronic ethanol self-administration also seem to depend on environmental variables, mainly housing conditions. Thus, it was demonstrated that $\mathrm{D} 2$ receptors are down-regulated by chronic ethanol treatment in rats housed in groups but not in socially isolated rats (22).

We also showed that ethanol significant- ly increased dopamine and DOPAC levels and decreased norepinephrine levels in the striatum after repeated treatment and 48 -h withdrawal. However, no alteration in norepinephrine levels was observed 30 min after drug administration. Studies (8) using

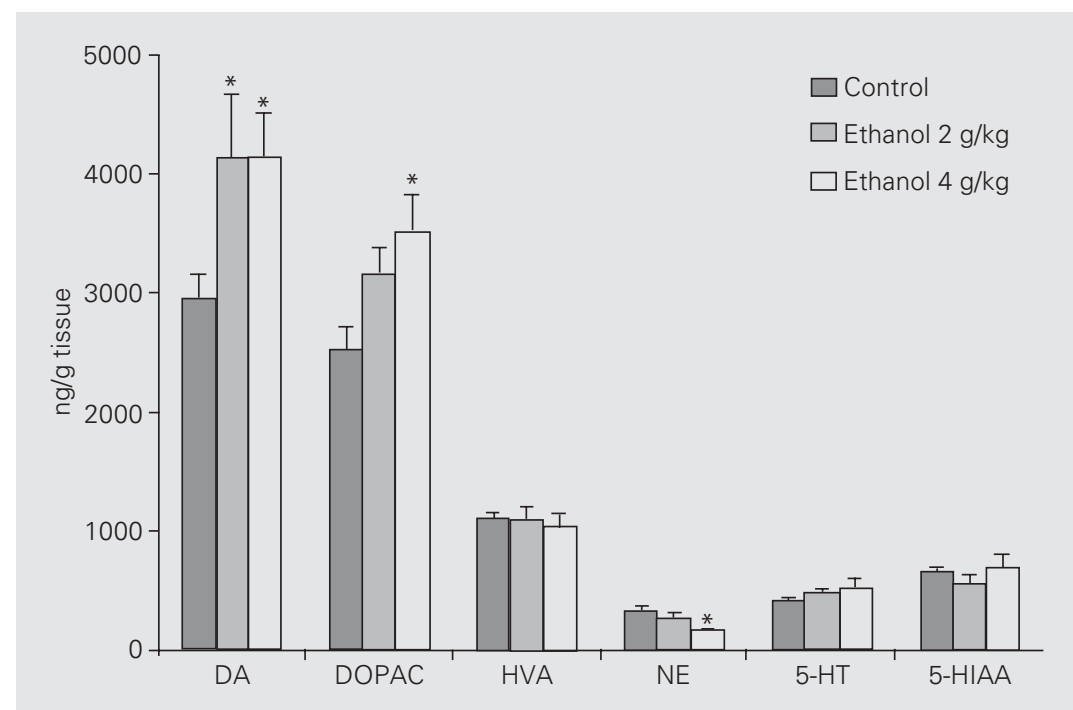

Figure 1. Concentrations of monoamines and metabolites in brain striatum from rats treated daily for 7 days with ethanol (2 or $4 \mathrm{~g} / \mathrm{kg}$, po) or distilled water (control). Animals were decapitated $48 \mathrm{~h}$ after the last ethanol administration. Data are reported as means $\pm \mathrm{SEM}$ $(\mathrm{N}=7-23) .{ }^{*} \mathrm{P}<0.05$ compared to control (ANOVA and Tukey as the post hoc test). DA: dopamine; DOPAC: 3,4-dihydroxyphenylacetic acid; HVA: homovanillic acid; NE, norepinephrine; 5-HT: serotonin; 5-HIAA: 5-hydroxyindoleacetic acid.

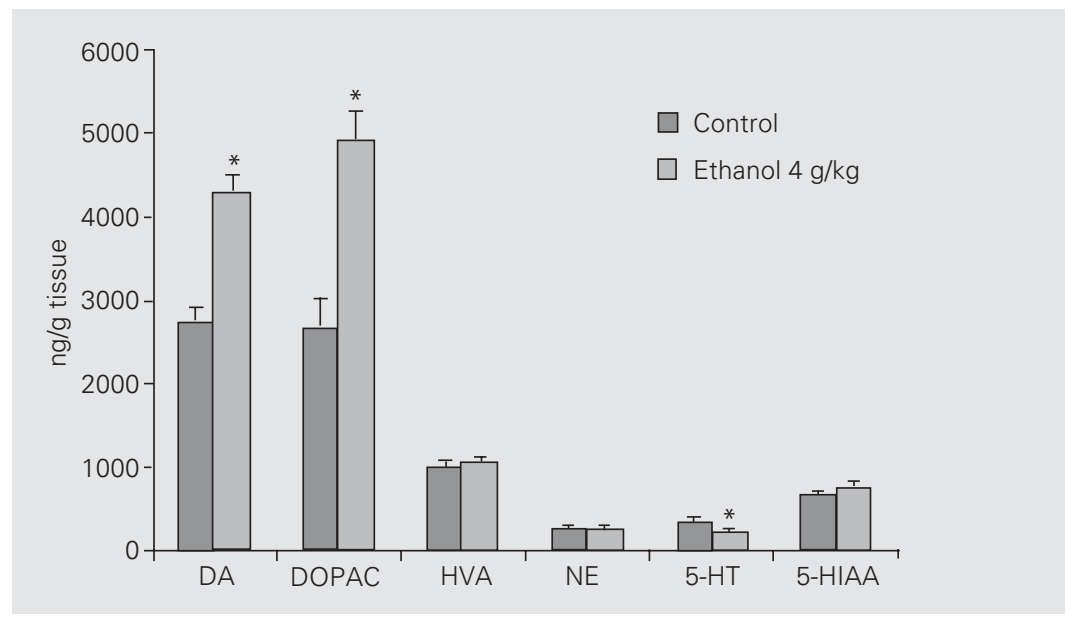

Figure 2. Concentrations of monoamines and metabolites in brain striatum from rats treated daily for 7 days with ethanol $(4 \mathrm{~g} / \mathrm{kg}$, po) or distilled water (control). Animals were decapitated 30 min after the last ethanol administration. Data are reported as means \pm SEM ( $N=7-23) .{ }^{*} \mathrm{P}<0.05$ compared to control (Student $t$-test). For abbreviations, see legend to Figure 1. 
doses of ethanol ranging from $1-2.5 \mathrm{~g} / \mathrm{kg}$ were able to demonstrate an increase in dopamine turnover and release in various brain areas during ethanol intoxication and, conversely, a dramatic decrease in dopamine release during ethanol withdrawal in the nucleus accumbens 2 to $12 \mathrm{~h}$ after the last treatment (23) and in the striatum (10). However, under these last experimental conditions, extracellular dopamine measurements were performed by the microdialysis technique in conscious animals, whereas we determined total striatal dopamine content ex vivo.

Gil et al. (24) detected noticeable decreases in dopamine and DOPAC levels in the rat striatum $24 \mathrm{~h}$ after ethanol withdrawal, following administration for 40 days. Other results (25) similar to ours demonstrated an increase in striatal dopamine after ethanol withdrawal. Rossetti et al. (10) found a biphasic effect on norepinephrine release in the frontal cortex, and while a low dose $(0.2 \mathrm{~g} / \mathrm{kg})$ raised norepinephrine outflow, a higher dose $(2 \mathrm{~g} / \mathrm{kg})$ inhibited its release. These investigators suggested that the decrease in cortical norepinephrine output may reflect the sedative-hypnotic properties of ethanol at high doses, whereas the increased norepinephrine release may represent a biochemical correlate of the arousal and increased alertness elicited by low doses of ethanol. Other studies (26) examining the turnover of norepinephrine and dopamine after 2 or 7 days of continuous ingestion of ethanol observed a reduction of dopamine in the striatum and an increase of norepinephrine in the brain stem about $8 \mathrm{~h}$ after ethanol withdrawal. These results suggest that changes in turnover of neurotransmitters in specific brain regions may reflect alterations in neuronal activity resulting from ethanol withdrawal or may be determinants of particular ethanol withdrawal symptoms.

We also demonstrated that after repeated ethanol administration and a 48-h withdrawal there are no changes in 5-HT, 5-HIAA or HVA levels. Although we failed to detect an alteration in 5-HT levels after $48 \mathrm{~h}$ of repeated ethanol treatment, a decrease was seen after 30 min of repeated ethanol administration. However, in this condition, increases in dopamine and DOPAC levels were also observed. Additionally, an increase in striatal dopamine and a decrease in 5-HT were simultaneously observed in ethanoldependent rats during ethanol withdrawal (25). Animal studies have indicated that acute ethanol exposure elevates 5-HT levels within the brain (27), suggesting either that more 5HT is released from serotonergic axons or that the neurotransmitter is cleared more slowly from the synapses. However, the general consensus is that there is an inverse relationship between the cerebral serotonergic system and ethanol drinking preference (1). Recent evidence $(27,28)$ has shown that levels of brain 5-HT and its metabolites were lower in alcohol-preferring rats than in nonpreferring ones. This observation supports the hypothesis that heavy drinking may partly represent an attempt to normalize 5-HT levels in key brain regions because acute alcohol consumption can elevate 5-HT levels.

It has been shown that drugs of abuse present different effects depending on the dose regimen, time of treatment, and withdrawal period $(29,30)$, suggesting that several factors are responsible for differences in the effects of ethanol. Thus, the neurochemical responses to ethanol represent a complex phenomenon influenced by variables including sex, strain, animal species, dose, duration of treatment, and time of drug withdrawal. Finally, we showed that repeated ethanol administration increased dopamine and DOPAC levels and tended to decrease norepinephrine levels in the rat striatum. In addition, down-regulation of D1 and D2 receptors was also observed, indicating that this phenomenon may be a consequence of the increase in dopamine levels in the synaptic cleft. Taken together, these findings indicate the involvement of the monoaminergic system in the responses to ethanol. 


\section{References}

1. Nevo I \& Hamon M (1995). Neurotransmitter and neuromodulatory mechanisms involved in alcohol abuse and alcoholism. Neurochemistry International, 26: 305-336.

2. Chandler LJ, Harris RA \& Crews FT (1998). Ethanol tolerance and synaptic plasticity. Trends in Pharmacological Sciences, 19: 491495.

3. Lograno DE, Matteo F, Trabucchi M, Govoni S, Cagiano R, Lacomba C \& Cuomo V (1993). Effects of chronic ethanol intake at a low dose on the rat brain dopaminergic system. Alcohol, 10: 45-49.

4. Hruska RE (1988). Effect of ethanol administration of striatal D1 and D2 receptors. Journal of Neurochemistry, 50: 1929-1933.

5. Pellegrino SM \& Druse MJ (1992). The effects of chronic ethanol consumption on the mesolimbic and nigrostriatal dopamine systems. Alcoholism: Clinical and Experimental Research, 16: 275-280.

6. Lucchi L, Moresco RM, Govoni S \& Trabucchi M (1988). Effect of chronic ethanol treatment on dopamine receptor subtypes in rat striatum. Brain Research, 449: 347-351.

7. DiChiara G \& Imperato A (1985). Ethanol preferentially stimulates dopamine release in the nucleus accumbens of freely moving rats. European Journal of Pharmacology, 115: 131-132.

8. Imperato A \& DiChiara G (1986). Preferential stimulation of dopamine release in the nucleus accumbens of freely moving rats by ethanol. Journal of Pharmacology and Experimental Therapeutics, 239: 219-228.

9. O'Brien CP, Eckardt MJ \& Linnoila VMI (1995). Pharmacotherapy of alcoholism. In: Bloom FE \& Kupfer DJ (Editors), Psychopharmacology: The Fourth Generation of Progress. Raven Press, New York, NY, USA, 1745-1755.

10. Rossetti ZL, Hmaidan Y \& Gessa GL (1992). Marked inhibition of mesolimbic dopamine release: a common feature of ethanol, morphine, cocaine and amphetamine abstinence in rats. European Journal of Pharmacology, 221: 227-234.

11. Koob GF, Wall TL \& Schafer J (1987). Rapid induction of tolerance to the antipunishment effects of ethanol. Alcohol, 4: 481-484.

12. Naranjo CA \& Sellers EM (1989). Serotonin uptake inhibitors attenuate ethanol intake in problem drinkers. Recent Developments in Alcoholism, 7: 255-266.

13. Brodie MS, Trifunovic RD \& Shefner AS (1995). Serotonin potentiates ethanol-induced excitation of ventral tegmental area neurons in brain slices from three different rat strains. Journal of Pharmacology and Experimental Therapeutics, 273: 1139-1146.

14. US Department of Health and Human Services. Institute of Laboratory Animal Resources (1985). Guide for the Care and Use of Laboratory Animals. National Research Council, Washington, DC, USA.

15. Meltzer HY, Matsubara S \& Lee JC (1989). Classification of typical and atypical antipsychotic drugs on the basis of dopamine D-1, D-2 and serotonin2 pKi values. Journal of Pharmacology and Experimental Therapeutics, 251: 238-246.

16. Kessler RM, Ansari MS, Schmidt DE, de Paulis T, Clanton JA, Innis R, al Tikriti M, Manning RG \& Gillespie D (1991). High affinity dopamine D2 receptor radioligands. 2. [125]]-Epidepride, a potent and specific radioligand for the characterization of striatal and extrastriatal dopamine D2 receptors. Life Sciences, 49: 617-628.
17. Lowry OH, Rosebrough NJ, Farr AL \& Randall RJ (1951). Protein measurement with the Folin phenol reagent. Journal of Biological Chemistry, 193: 265-275.

18. Gili-Martín E, Fernandez-Briera A \& Calvo P (1997). Effects of chronic ethanol treatment and ethanol withdrawal on $\left[{ }^{3} \mathrm{H}\right]-\mathrm{SCH}-23390$ binding to rat striatal membranes. Neuropharmacology, 36: 101-106.

19. Hamdi A \& Prasad C (1993). Bidirectional changes in striatal D1dopamine receptor density during chronic ethanol intake. Life Sciences, 52: 251-257.

20. Souza-Formigoni ML, De Lucca EM, Hipolide DC, Enns SC, Oliveira MG \& Nobrega JN (1999). Sensitization to ethanol's stimulant effect is associated with region-specific increases in brain D2 receptor binding. Psychopharmacology, 146: 262-267.

21. Syvalahti EK, Hietala J, Roytta M \& Gronroos J (1988). Decrease in the number of rat brain dopamine and muscarinic receptors after chronic alcohol intake. Pharmacology and Toxicology, 62: 210-212.

22. Rilke O, May T, Oehler J \& Wolffgramm J (1995). Influences of housing conditions and ethanol intake on binding characteristics of D2, 5-HT1A, and benzodiazepine receptors of rats. Pharmacology, Biochemistry and Behavior, 52: 23-28.

23. Diana M, Pistis M, Carboni S, Gessa GL \& Rossetti ZL (1993). Profound decrement of mesolimbic dopaminergic neuronal activity during ethanol withdrawal syndrome in rats: electrophysiological and biochemical evidence. Proceedings of the National Academy of Sciences, USA, 90: 7966-7969.

24. Gil E, Colado I, Lopez F, Fernandez-Briera A, Fernandez-Lopez A \& Calvo $P$ (1992). Effects of chronic treatment with ethanol and withdrawal of ethanol on levels of dopamine, 3,4-dihydroxyphenylacetic acid and homovanillic acid in the striatum of the rat. Influence of benzodiazepines, barbiturate and somatostatin. Neuropharmacology, 31: 1151-1156.

25. Mirovsky Y, Yu YL, Wagner GC, Sekowski A, Goldberg M \& Fisher H (1995). Novel synergistic treatment of ethanol withdrawal seizures in rats with dopamine and serotonin agonists. Alcoholism: Clinical and Experimental Research, 19: 160-163.

26. Eisenhofer G, Szabo G \& Hoffman PL (1990). Opposite changes in turnover of noradrenaline and dopamine in the CNS of ethanoldependent mice. Neuropharmacology, 29: 37-45.

27. Le Marquand D, Pihl RO \& Benkelfat C (1994). Serotonin and alcohol intake, abuse, and dependence: Clinical evidence. Biological Psychiatry, 36: 326-337.

28. McBride WJ, Bodart B, Lumeng L \& Li TK (1995). Association between low contents of dopamine and serotonin in the nucleus accumbens and high alcohol preference. Alcoholism: Clinical and Experimental Research, 19: 1420-1422.

29. Boone EM, Cook MN, Hou X \& Jones BC (1997). Sex and strain influence the effect of ethanol on central monoamines. Journal of Studies on Alcohol, 58: 590-599.

30. Shimada M, Murayama N, Nagata K, Hashimoto H, Ishikawa H \& Yamazoe $Y$ (1997). A specific loss of growth hormone abolished sexdependent expression of hepatic cytochrome P450 in dwarf rats: reversal of the profiles by growth hormone-treatment. Archives of Biochemistry and Biophysics, 337: 34-42. 